Paedagogia Christiana

2/46 (2020) - ISSN 1505-6872

DOI: http://dx.doi.org/10.12775/PCh.2020.023

Matgorzata Fopka-Kowalczyk*

ORCID: 0000-0002-5785-6227

Toruń, Poland

\title{
Providing Support and Spiritual Care to People with Chronic Diseases
}

\author{
Wsparcie i opieka duchowa \\ w relacji z chorym przewlekle
}

\begin{abstract}
Chronic disease is an extremely difficult situation for those who experience it during their lives. It changes their entire world, influencing their feelings, behaviour, tasks, and roles. For many people it can be defined as a difficult or even limit situation, i.e. one that affects the whole person emotionally, socially, physically, and spiritually. Contemporary literature, particularly English-speaking scientific communities, has increasingly emphasised the importance of taking care not only of somatic ailments but also of spiritual existential questions about the meaning of life, suffering, and dying. Since it is of such importance, it is also necessary to ask how spiritual care can be provided to people with long-term diseases.
\end{abstract}

Keywords: long-term disease; patient; spirituality; total pain; spiritual support; spiritual care.

* Dr. Małgorzata Fopka-Kowalczyk, Department of Revalidation, Rehabilitation and Long-Term Care, Faculty of Philosophy and Social Sciences, Nicolaus Copernicus University in Toruń, Poland; email: mfopka-kowalczyk@umk.pl. 


\begin{abstract}
Abstrakt: Choroba przewlekła to jedna z najtrudniejszych sytuacji dla człowieka, który jej doświadcza w swoim życiu. Zmienia cały świat osoby chorej, wpływając na emocje, zachowanie, zadania i pełnione role. Przez wielu może być oceniana jako sytuacja trudna, a nawet graniczna, czyli obejmująca całego człowieka w życiu emocjonalnym, społecznym, fizycznym oraz duchowym. Współczesna literatura, zwłaszcza zagraniczna, podkreśla coraz częściej znaczenie objęcia troską nie tylko dolegliwości somatycznych, ale też trudności duchowych. Ta uważność duchowa i okazane współczucie mogą stać się podstawą do lepszego radzenia sobie i znalezienia odpowiedzi na egzystencjalne pytania dotyczące sensu życia, cierpienia i umierania. Jeśli troska duchowa jest tak istotna, to należy też zadać pytanie, w jaki sposób można to wsparcie duchowe osobom chorym okazywać.
\end{abstract}

Słowa kluczowe: choroba przewlekła; chory; duchowość; ból totalny; wsparcie duchowe.

Man does not simply exist, but always decides what his existence will be, what he will become in the next moment.

Frankl (1985, p. 154).

\title{
1. Introduction
}

Chronic diseases are generally perceived to be among the most difficult experiences people may endure throughout their lives. This opinion results not only from the fact that they lead to significant disability and death but also because they limit the functioning of patients on many levels. Patients' experiences show that such situations may be approached in two ways: on the one hand, a long-term illness is often defined as a limit situation that raises questions about the meaning of suffering, death, and diseases; on the other hand, as highlighted by Viktor Frankl (2017, p. 124), it can also be a time of positive change whereby the limit situation or life crisis inspires reflection and 'the experience of suffering leads to greater maturity'. Each of these situations prompts questions about the meaning and significance of such crises, life values, beliefs, worldviews, faith, and relationships with other people, oneself and God. In the modern world, people are paying more attention not only to somatic ailments but also to social, emotional, and spiritual aspects of relationships with the chronically ill; we are asking questions through the 
prism of spiritual experience, 'a kind of meta-sphere that covers, or rather permeates all forms and areas of life' (Kapała, 2017, p. 9).

This article is a result of theoretical analyses and the author's own experience in work with chronic patients. The experiences of these patients are discussed in terms of limit situations, with dilemmas and existential questions addressed as spiritual experiences. While related research increasingly shows that 'people cannot do without spirituality' (Comte-Sponville, 2011, p. 142), this paper seeks to relate the category of spirituality to chronic illness. The following concepts are discussed: chronic (long-term) disease as a limit situation, spiritual experience and its recognition in chronic disease, and ways of providing care and support to chronic patients in terms of spiritual experiences. Based on the subject literature, the author also tries to define the notions of care, sensitivity, and spiritual support in professional work with patients. If spiritual support is recognised as a positive component of work with chronic patients, which forms of such support are most appropriate? All of these issues are addressed in the respective sections below.

\section{Chronic disease as a limit situation. The model of total suffering}

There are many definitions of health depending on the adopted paradigm, model, or concept of health and illness. One of them defines chronic disease as a condition of long duration, generally slow in progression (Reynolds et al., 2018, p. 11). The most important characteristics typical of longterm illnesses include:

- Long duration (over three months);

- Progressing or recurring symptoms, typically with poor prognosis;

- The need for continuous hospitalisation for at least one month;

- Frequently permanent and irreversible changes in the body which significantly limit or impair the patient's functional independence;

- Chronic disease typically requires specific drug management to prevent its progression, but is incurable (Markocka-Mączka et al., 2016; Reynolds et al., 2018; Ziarko, 2014, as cited in Fopka-Kowalczyk, 2017).

The disease may therefore limit or rapidly change a patient's life, affecting their perception of themselves, emotional reaction style, and ability to cope with new situations. Accompanied by physical and psychological discomfort caused by disease-induced pain and other symptoms, it often pre- 
vents patients from functioning in their current roles, affecting their quality of life (Grochans et al., 2012, p. 543). Due to the individual, difficult, and sometimes extremely intimate nature of their experiences, chronic patients have often described their situation as a crisis or limit situation (Klimasiński et al., 2017a). Throughout our lives, everyone is confronted with a difficult situation or crisis which is difficult to deal with and makes us feel helpless (Marek \& Walulik, 2012, p. 179). 'Exposing a person and his or her deepest spiritual and psychological layers' (Tatar, 2012, p. 140), suffering is an example of limit situation (Marek \& Walulik, 2012, p. 179). Karl Jaspers' works suggest that, rather than being dictated by the situation itself, the experience of limit situations is directed by the way in which one relates to it and interprets it (Kolasa, 2010, p. 136). In limit situations people adopt a certain way to confront their suffering while experiencing a variety of emotional and mental states. Consequently, they find themselves looking for answers both about the self and the world around them.

Thrust into a limit situation, I encounter myself as this mortal, fallible, and vulnerable being, defined by my inborn and acquired predispositions, and conditions in which I happen to live, I discover myself with certain limits ... I can't avoid death, isolation, suffering, struggle, or guilt. No matter how much I would want to, I can't change many of the circumstances that have defined my life. (Wojdała, 2016, p. 80)

The diagnosis of chronic disease may be experienced differently and defined individually by each patient. On the one hand, it is often perceived as something to get rid of, prevent, or overcome as an unwanted situation. If it lasts longer and the current coping mechanisms prove to be insufficient or fail, emotional tension, crisis, and suffering may appear, eventually leading to defiance, bitterness, and lack of acceptance (Marek and Walulik, 2012, p. 180). On the other hand, suffering can protect people against apathy, giving them a chance to mature (Klimasiński et al., 2017b, p. 211; Tatar, 2012, p. 137) and grow: 'it makes us richer and stronger' (Frankl, 2017, p. 127). The recognition and experience of chronic illness can have various consequences. It may be a reason to escape, with tension and crisis building up, or a period of growth and maturity. 'Suffering may help a person discover spiritual, ethical, and religious values' (Marek \& Walulik, 2012, p. 180).

While a chronic disease may trigger positive changes in life (e.g. when perceived as a reason to change one's life or as a uniting force within an oth- 
erwise conflicted family) ${ }^{1}$ (e.g. Świętochowski, 2010, p. 25), in most cases, particularly immediately after diagnosis, it evokes a variety of negative experiences such as denial, disbelief, anger, sadness, and depression (Kübler-Ross, 2007). A common reaction from patients is the belief that the diagnosis has turned their world upside down and changed their life. This is the point at which they most often ask questions about the meaning of their suffering and experiences, the fate and future of their own and loved ones, and finally about God and his existence. When life is limited due to disability and imminent death, questions are asked that reach into the deepest layers of humanity. 'Humans are the only beings in the world that seek meaning. Once they find it, they regain their inner strength to face the hardships of life and cope with adversities' (Muszala, 2017b).

Limit experiences, present in all spheres of patients' lives, have also been discussed in terms of holistic models of patient care (Anandarajah, 2005; Kapała, 2017, p. 9). Such models are characteristic of palliative care and psycho-oncology, to which Cicely Saunders' concept of total pain applies (Saunders, 2004). She argues that care should be provided to patients in all aspects of life: somatic, social, emotional, and spiritual (Binnebesel, 2003, pp. 20-21; Saunders, 2004; Winkler, 1996, p. 69). Further evidence from Kübler-Ross (2007, pp. 55-146) supports the concept of total pain, demonstrating that disease can change the patient's emotional reactivity or adaptation levels to a new situation. The experience also affects patients in their roles, restricting their ability to perform certain duties and forcing them to delegate. Another fundamental difficulty is coping with the loss of abilities and functional independence as the disease progresses and causes disability (Kurpas et al., 2012, p. 397), or makes patients unable to work and pursue their dreams and plans (Block, 2006, pp. 48-49; Bohusz-Dobosz, 2004, p. 58).

Considering the factors introduced above, the experience of a disease is not solely limited to the somatic sphere but concerns a wider range of emotional, social, and spiritual states as an integral part of the patient's overall experience. Indeed, 'the unity of the physical and the psychological by no means exhausts human wholeness. To ensure human wholeness, a third fac-

${ }^{1}$ Psycho-oncology literature shows that disease can be defined in many different ways: as a punishment, as a message from God/the fate/the body, as an obstacle to overcome, as an insurmountable obstacle, as a value, as a gift, as something beneficial, etc. Each of these perceptions triggers specific changes in chronic patients' lives which subsequently have an impact on their approach to illness and therapy, beliefs regarding life and suffering, relationships with others, and perception of self. 
tor is necessary, a crucial one - the spiritual factor' (Mikołajczak, 2017). If spiritual needs and pain emerge from the patient's questions, another important step is an attempt to answer the following question: 'Is there a space for presence in a limit situation?' (Opoczyńska, 2010, as cited in Wojdała, 2016, p. 81), a presence that is special and intimate which gives patients a chance to have their questions heard and answered? Is it possible to offer presence, defined as care and support, to people in a limit situation of a disease that affects all spheres of their life? Furthermore, is it necessary and appropriate to attend not only to physical aspects of the ill? Finally, is compassion - understood as 'suffering with' (Larkin, 2018) combined with sensitivity, thus providing for a special and intimate spiritual relationship with the patient possible?

\section{Spirituality and the spiritual needs of chronic patients}

The extant literature highlights a centuries-old relationship between medicine and spirituality (Klimasiński et al., 2017a), while contemporary reports suggest that medicine can also be a spiritual discipline (Swinton et al., 2017, p. 199). Given Saunders's concept of total pain and the perception of chronic disease as a limit situation, it is possible to address not only purely medical issues but also the spiritual sphere in a relationship with the patient. At this point, it is important to point out that rather than being understood as a practice or practices resulting from denominational affiliation, spirituality is very broadly defined as a state characteristic of every human being, even by those who declare themselves as non-believers (Krakowiak \& Fopka-Kowalczyk, 2015 , p. 60); this is because it refers to 'what is most human, what distinguishes a man as such' (Frankl, 1971, as cited in Fabiś, 2015, p. 15). Spirituality is an important part of life that transcends sensory phenomena (Klimasiński et al., 2017b, p. 211) while also having an impact on and shaping every level of people's personal and social lives (Kapała, 2017, p. 9).

The World Health Organisation (WHO) defines spirituality as a primary dimension of health that can support people in the conditions of stress (ibidem, p. 199). It is also 'that aspect of humanity that is expressed in the way people seek and give meaning and purpose to their existence, and in the way they experience the connection to the present moment, self, other people, nature, to what constitutes the essence and the sacred' (Puchalski et al., 2009 , p. 886). These definitions may be further supplemented by the category of spirituality as defined by the Association of American Medical Colleges 
(AAMC), according to which spirituality is 'participation in religion and/or belief in God, family, naturalism, rationalism, humanism, and the arts' (AAMC, 1999). Moreover, the Pontifical Council for the Pastoral Assistance to Health Care Workers says that spirituality is about 'a loving presence which is full of attention and concern, and which instils trust and hope, replacing, thereby, a refusal of death with its acceptance' (Honings, 1995). Another definition was proposed by the European Association for Palliative Care (EAPC) Task Force; emphasising the multidimensional nature of the spiritual field, it sets a direction for the work of medical and non-medical staff with patients and specifies their role in improving the patient's quality of life during this difficult period through spiritual care. The EAPC Task Force defines spirituality as:

Spirituality is the dynamic dimension of human life that relates to the way persons (individual and community) experience, express and/or seek meaning, purpose and transcendence, and the way they connect to the moment, to self, to others, to nature, to the significant and/or the sacred. (Best at al., 2020, p. 2)

This definition of spirituality is particularly broad, not limited only to the spiritual experiences of believers but emphasising the possibility of spiritual experience in every person regardless of faith or religious practices. According to the author, this way of presenting spiritual experiences seems to best reflect the spiritual experiences of chronic patients while setting a direction for different methods of professional care. It not only includes religious and transcendent aspects attributed to a specific religion, but also points out the dimension of spiritual experiences through relationships with the self, other people, nature, and the world of values.

Based on the definitions of spirituality outlined above dimensions of spiritual experiences have been proposed, allowing us to recognise the nature of spiritual experiences and needs. They are presented in the following sections of this article.

As this text discusses the possibility of spiritual experiences in every individual, including non-believers, one needs to make a distinction between spirituality and religiosity and clarify both terms. The religious dimension is associated particularly with religious institutions and practices, as well as a declared affiliation with a certain religious group. Religion is treated as a social and institutionalised phenomenon. In contrast, the spiritual dimension is perceived as a person's use of their individual and personal resources to experience God, themselves and others regardless of any declared denominational affiliation (Krakowiak \& Fopka-Kowalczyk, 2015). This distinction 
is especially important in the context of spiritual support for patients who are non-believers or have different religious views in comparison to the carer. With the spiritual or religious needs resurfacing, particularly upon a significant deterioration in health and realisation of impending death (Klimasiński et al., 2017a), the ability to care for this specific area seems to be just as important as pain management.

This spiritual dimension seems to be most discussed in the context of palliative care, where spiritual support services form part of the quality standards on care in the last days of life (NICE, 2004). However, it is becoming increasingly prominent in other fields as a result of research revealing a positive relationship between spirituality and coping with a disease, not only during the advanced stages but throughout the entire course of treatment. For example, Szparkowska shows that spirituality helps patients deal with the long-term burden of the disease (Szparkowska, 2013); indeed, despite the characteristic fatigue and pain, spiritual support helps patients find self-confidence, meaning of life, and comfort (Klimasiński, 2017a, p. 2). For the chronically ill, it is of utmost importance that such support is never provided at the expense of medical care but rather as a complementary element of overall care. Patients clearly need to be talked and listened to rather than 'preached' or 'converted' by their physician. What is important to them is the compassion of medical staff and their openness to issues raised by patients, including those with spiritual connotations (ibidem, p. 4). Other studies show that spiritual support has the following effects:

1. Better adaptation to a chronic somatic disease;

2. A more favourable attitude to treatment;

3. Cancer patients with a higher level of spirituality:

- Assessed their current condition as better;

- Felt they had more influence on the course of the disease;

- Presented lower levels of anxiety and depression;

- Were less prone to react with fear;

- Were more often optimistic in their predictions about the progress of the disease (Heszen-Niejodek \& Gruszczyńska, 2004, pp. 15-34);

- Had a better overall quality of life, were more able to cope with a disease, could recover from a surgical procedure or an episode of depression, and had a more positive attitude despite a difficult health situation (Brady et al., 1999).

The vast majority of cancer patients view religiosity or spirituality as essential or significant aspects of their lives. They say it can influence the 
perception of comfort, give a sense of control, enhance their approach to the meaning of things, and increase the maturity of patients with life-threatening diseases (van Laarhoven et al., 2010, p. 496).

The presented relationships with quality of life, disease and coping with the disease, and the received spiritual support confirm that spirituality is an essential part of human life (Vandenhoeck, 2013); as such, it should be an integral element of comprehensive patient care. 'Spiritual care is as important as strictly medical or psychological care, and cannot be treated as an "accessory" or as that last word when the doctor stands there helplessly and says that "nothing more can be done"' (Muszala, 2017a, p. 125). It should be provided not so much incidentally but rather as an integral part related to purely medical care as an element of professional medical care (Vandenhoeck, 2017). If this is the case, how should we care for patients' spiritual sphere to ensure the best possible support that corresponds to their needs?

\section{Diagnosis of suffering and spiritual needs}

To ensure proper and adequate spiritual support, one needs to be able to recognise people's spiritual experiences. Firstly, as pointed out by Gowri Anandarajah and Ellen Hight (2001, p. 84), one has to establish whether the spiritual sphere is important to the patient and whether spiritual factors can help this individual with the treatment. Determining spiritual needs is therefore essential both for the medical assessment and diagnosis and for subsequent support in the doctor-patient relationship.

The subject literature captures spiritual needs in terms of dimensions of spiritual experiences that are analysed and characterised. Moreover, rather than simply pertaining to the period of dying, these needs are prevalent from the original diagnosis to the subsequent stages of treatment and progression of the disease. The spiritual needs will therefore include, inter alia, seeking answers to questions about meaning, inner balance, relations, and transcendence. The following are listed among the most frequently reported spiritual needs of chronic patients:

- The need to be accompanied in the difficult situation they are experiencing;

- The need for peace;

- The need to reconcile with God and people;

- The need for love;

- $\quad$ The need to find the meaning of life; 
- The need for transcendence;

- The need to have a chance for thanksgiving and forgiveness (Klimasiński et al., 2017a, p. 2).

As already pointed out, the subject literature defines different dimensions of spiritual experiences. The analysis within these studies provides the basis for presenting each experience in the context of individual needs. One such classification identifies spiritual dimensions by highlighting specific levels of spiritual experiences in the following spheres of functioning (Anandarajah, 2005):

1. 'Cognitive aspects, which refer to how a person understands the world around him or her. The prevailing need is to seek and find answers to questions about the nature of the universe, the existence of God, the meaning of bad things happening to good people, life after death, personal values and beliefs, and their meaning in life.

2. Experiantial aspects, which include questions such as: 'Am I alone, or am I part of something greater?', 'Am I capable of giving and receiving love?', 'Do I have the inner sense of peace and resilience?', 'Can I find hope in this difficult situation?'.

3. Behavioral aspects, which include dilemmas based on which it is possible to recognise how spiritual beliefs affect human behaviour and life choices. Behavioural symptoms allow us to recognise whether a person requires spiritual support and provide a framework for discussing these topics'.

Another classification of the dimensions of spiritual experiences was proposed by Christina Puchalski, who used it to develop a qualitative tool for talking to patients about their experiences and spiritual needs (Borneman et al., 2010; Puchalski \& Romer, 2000). Within this FICA Tool, questions are asked to learn more about the following dimensions:

- F - The importance of spiritual values and beliefs in the patient's life, the role of religion and religious practices, and self-defining as a believer;

- I - Learning what is most important to the patient;

- C - The importance and role of the broadly defined community in the patient's life and in coping with the experienced situation;

- A - The importance of and need for spiritual care and for the staff to address spiritual issues as part of the care process (Puchalski \& Romer, 2000).

The needs identified by Puchalski include the need to find answers to questions about oneself and one's place in the world, one's life, the nature 
of the relationship with God, and the associated emotions and dilemmas (the need for God's presence/the experience of the lack of closeness and love, and the need to change it). Another one is the need for forgiveness and an increased focus on relations with people/God (e.g. seeking improvement, closeness) (Klimasiński et al., 2017a, p. 2).

Richard Groves also offers a classification of spiritual dimensions, distinguishing the following needs in those who ask spiritual questions:

- Meaning/sense, when people seek answers about the sense and meaning of life or the meaning of their own existence, achievements, worth, and actions;

- Relations, when people seek closeness or change in the nature of their relationship with others/God;

- Forgiveness, when people desire forgiveness from others but also for others and for themselves;

- Hope (Groves \& Klauser, 2009). ${ }^{2}$

According to Groves, asking the patient to evaluate (on a scale from 1 to 5) his or her own spiritual experiences in each of the defined dimensions allows the carer to assess the extent of the patient's spiritual dilemmas and needs, their importance, and the need for support in this area (ibidem).

Another interesting classification was established by Gowri Anandarajah (Anandarajah \& Hight, 2001, p. 1), who used it to develop her research tool for diagnosing spiritual needs in people. Her assessment scale addresses specific issues which can help carers get to know the patient and consequently provide care and support best suited to the patient's individual situation and spiritual needs. The HOPE approach focuses on:

- $\mathrm{H}$ - The sources of hope, meaning in life, comfort, strength, peace, love, and relations;

- $\mathrm{O}$ - Organised religion and its importance in human life, particularly in crisis situations, and being part of a community;

- $\quad \mathrm{P}$ - Personal spirituality and spiritual practices;

- E - Effects of the patient's beliefs and values on medical care and end-of-life decisions (ibidem).

A further classification that refers to specific spiritual dimensions is offered within Polish literature. In his analyses of spiritual experiences, Zbigniew Pawlak points out the negative aspects of spiritual suffering:

2 More information about the Spiritual Health Assessment (SHA) tool designed by Richard and Mary Groves (Healing through Awareness) can be found at: www.sacredartofliving.org. 
1. Loneliness - 'excused from life', when patients feel that they no longer belong to the community of healthy, active people who make plans for the future;

2. Lack of meaning or purpose, emptiness - existential thoughts prevail and cause spiritual suffering: questions about the meaning of human fate, life and death, dilemmas and questions about God and his love, particularly in the context of experienced suffering, what happens after death;

3. Anxiety - due to moral dilemmas and a sense of responsibility for the life as lived until the end (Pawlak, 2000).

A key factor in spiritual suffering to highlight at this point is the fear of loneliness in the moment of illness and dying, as well as the fear of the unknown (Block, 2006, p. 49). According to de Walden-Gałuszko (1992, p. 55), it can also be related to the thanatic fear, the basic components of which include:

1. Fear of dying, particularly of symptoms that accompany it, such as dyspnoea, pain, or losing control of the body;

2. Fear of being dead, or fear of the unknown and of God's judgment;

3. Fear of the consequences of death, or fear of what will happen to the body after death;

4. Fear of the consequences of death for loved ones or anxiety about the fate of one's partner or children.

In summary, among the aforementioned dimensions that could indicate the need for talking or spiritual support, the following aspects are primarily emphasised:

- Existential questions about identity, meaning, suffering and death, guilt and shame, reconciliation and forgiveness, freedom and responsibility, hope and despair, love and joy;

- Values-based opinions and attitudes (i.e. one's relationship with oneself, family, friends, work, things, nature, arts, and culture);

- Reflections upon religion and principles (faith, beliefs, customs, one's relationship with God with existence in a broader sense) (Nolan et al., 2011).

Most patients use symbolic language or metaphors when discussing spiritual issues; hence, the assessment and recognition of spiritual experiences will most frequently consist, first of all, of listening carefully to patients' stories about their lives and illnesses before subsequently interpreting the related spiritual problems (Anandarajah, 2005; Anandarajah \& Hight, 2001). The ability of professionals to recognise these experiences and the readiness 
to ask patients what is important to them in life facilitates a conversation about spiritual needs and dilemmas, consequently enabling carers to provide support adequate to patients' current needs. The psychological and pedagogical literature defines this competence in terms of hard and soft social skills; the former are skills documented with education and certificates, while the latter are interpersonal skills (Balawajder, 1996, p. 46; Argyle \& Knox, as cited in Urbański-Korż, 2000, pp. 9-10), particularly in the field of asking questions, showing interest, active listening, and paying attention to verbal and non-verbal communication.

For Magdalena Kapała (2017), spiritual sensitivity allows a professional not only to establish a rapport with patients but also recognise that they are going through a difficult situation. Spiritual sensitivity is understood as 'the disposition to experience spirituality, manifested by approaching events in terms of a transcendent and ultimate perspective, moral sensitivity, and the ability to find meaning in paradoxical and limit situations' (ibidem, p. 7). From this perspective, competences such as a comprehensive approach to patients' experiences, openness to other people, a sense of the importance of spirituality in life, ethical and moral sensitivity, and involvement in the affairs of another person are particularly important (ibidem). Another quality, essential in those who provide spiritual support, is spiritual intelligence, defined as the ability to 'sort out issues regarding the meaning of life and values. It allows us to put our actions in a broader, richer, and more meaningful context, and decide which of our life choices is more valuable ...' (Mausch, 2018, p. 92). People with spiritual intelligence are capable of a deeper understanding of others, are convinced of the existence of the transcendent, and know how to listen to others. Having experienced a difficult situation themselves or having been witnesses to spiritual experiences in another person, they are ready to try to understand the pain of the other individual and help find answers to philosophical or existential questions (ibidem). As well as evidently being important in establishing relationships with chronic patients, these skills also seem to be vital in recognising spiritual experiences or suffering and providing spiritual support.

\section{Support and spiritual care}

Support is generally defined as helping someone in a difficult situation where the individual in question cannot manage on their own and requires emotional reinforcement, information or instruction, material help, or as- 
sistance in solving spiritual or existential dilemmas (Sęk \& Cieślak, 2006, p. 18). Its aim should be to help a lost person who has difficulty in coping with a specific situation on their own due to external factors. On the other hand, in a more comprehensive sense, spiritual care can be defined as recognising and responding to the 'multifaceted expressions of spirituality we encounter in our patients and their families. It involves compassion, presence, listening and the encouragement of realistic hope, and might not involve any discussion of God or religion' (Derrickson, 1996 and O'Connor, 1986, as cited in Anandarajah \& Hight, 2001, p. 84). Due to the semantic similarity of these two categories, for the purposes of this article they are perceived as identical in meaning and thus used interchangeably in the text. ${ }^{3}$

Support or spiritual care can be provided by any person (Anandarajah \& Hight, 2001, p. 84; Klimasiński et al., 2017b, p. 214). General spiritual care includes showing compassion, listening to another person, and being present. Specific or specialised support is the domain of those professionally prepared, such as chaplains trained for this purpose. ${ }^{4}$ Christina Puchalski identifies the following fundamental principles of providing spiritual care:

1. Noncoercive behaviour and a patient-centred approach;

2. Keeping professional boundaries: no abuse of the patient's trust;

3. Broad definition of spirituality;

4. Avoidance of trying to answer unanswerable questions ('why me?'; 'why now?');

5. Not going beyond one's level of expertise;

6. Recognition of pastoral care professionals as experts;

7. Proselytisation is not acceptable in a professional setting;

8. More in-depth spiritual counselling should be under the direction of chaplains and other spiritual leaders;

9. Praying with patients (Puchalski, 2013).

${ }^{3}$ In pedagogy, support is a symmetrical act where a person is treated like a partner and where help is provided only in situations that a person currently cannot handle on his/her own. Care is asymmetrical and is addressed to people who are unable to function independently and require comprehensive assistance. It is rather continuous and unconditional, with carers taking responsibility for the person in their care (e.g. small children, people with advanced disease/in palliative care, functionally dependent, bed-ridden patients) (cf. e.g. Jundziłł \& Pawłowska, 2008, p. 171).

${ }^{4}$ In some European countries (e.g. Germany) and the United States, special courses are provided (e.g. Clinical Pastoral Education for hospital chaplains) to educate people in the field of support and spiritual care: www.healthcarechaplaincy.org; www.spiritualcareassociation.org. 
The subject literature discusses specific forms of spiritual support and these essentially involve selecting a specific form of care based on the previous diagnosis of the patient's spiritual experiences and needs. The proper assessment of the patient's spiritual condition allows carers to make the right decision about the form of spiritual care; it may for example come in the form of individual or community-based spiritual care (sacramental or non-sacramental support). At this point, it is worth pointing out that the former is the domain of people with appropriate training - representatives of specific religious communities - and this expertise provides patients with access to all possible religious practices and sacraments in accordance with their worldview and faith.

As for non-sacramental forms of spiritual care, the following are identified:

1. Talking about spiritual matters that concern the patient;

2. Searching for answers to spiritual dilemmas with the use of the Bible, films, or books on spiritual topics;

3. Treating spirituality as a human resource (as something that will allow me to..., will make it easier to..., will change..., etc.);

4. Assisting in making difficult decisions (saying goodbye, writing letters, reconciliation, forgiving);

5. Keeping company with the patient as a silent presence;

6. Being honest with the patient and oneself (I don't know why you are ill);

7. Working on cognitive schemata concerning one's life, oneself, and the sense of treatment.

Employing these principles within support and spiritual care seems to be beneficial for patients, enabling them to openly discuss existential matters, care, and support.

By providing support and spiritual care to patients, physicians and other professionals are often exposed to the associated emotional costs. In this context, physicians' self-awareness and self-understanding of their own spirituality, values, beliefs, faith, and development of the ability to self-care may be useful (Anandarajah \& Hight, 2001). Self-care and self-understanding can help doctors prepare for the difficult questions asked by their patients, for instance 'why me?' These processes can also help them prepare for situations in which the patient asks them about spiritual matters or for a prayer. 


\section{Conclusions}

Contemporary literature on spirituality argues that 'the most important moment of treatment is when the tools have been put away, and the doctor is nearby' (Wojdała, 2016, p. 83). The concept of total pain points to the need for comprehensive care for chronic patients, an increasingly important part of which is spiritual care; this element is vital for the patient's care to become both integral and adequate. Assuming that physical care fails to provide sufficient engagement with the patient, accepting the invitation to his or her inner world of emotional and spiritual experiences is not only conducive to establishing trust and better contact in the professional-patient relationship (thus becoming a key part of the treatment process) but will also provide the basis for care and support throughout the patient's broadly defined spiritual experience. Experienced healthcare professionals know that in many cases there is little they can offer to their patients in terms of medical solutions and therapies. Including spirituality in preventive healthcare may help identify and mobilise one's own spiritual resources as a source of strength in finding balance and answering questions about life, God, and oneself (Anandarajah \& Hight, 2001, p. 86). In essence, 'ill people do not live just to fight their illness. They live to enjoy their unique lives and pursue their calling' (Krajnik, 2017).

\section{References}

Anandarajah, G. \& Hight, E. (2001). Spirituality and Medical Practice: Using the HOPE Questions as a Practical Tool for Spiritual Assessment. American Family Physician, 63, 81-88.

Anandarajah, G. (2005). Doing a Culturally Sensitive Spiritual Assessment: Recognizing Spiritual Themes and Using The HOPE Questions. Virtual Mentor. Ethics Journal of the American Medical Association, 7, 5. Retrieved Mai 5, 2020 from https://journalofethics.ama-assn.org/sites/journalofethics.ama-assn. org/files/2018-06/cprl1-0505.pdf.

Association of American Medical Colleges (AAMC) (1999). Report III. Contemporary issues in medicine: communication in Medicine. Retrieved January 2, 2020, from https://members.aamc.org/eweb/upload/Contemporary\%20Issues \%20In\%20Med\%20Commun\%20in\%20Medicine\%20Report\%20III\%20.pdf. 
Balawajder, K. (1996). Umiejętności interpersonalne w niesieniu pomocy innym. In K. Popiołek (Ed.), Psychologia pomocy. Katowice: Wydawnictwo UŚ.

Best, M., Leget, C., Goodhead A. \& Paal P. (2020). An EAPC white paper on multi-disciplinary education for spiritual care in palliative Care. BMC Palliative Care. Retrieved October 25, 2020 form file://C:/Users/DB/Downloads/s12904-0190508-4.pdf.

Binnebesel, J. (2003). Opieka nad dziećmi i młodzieża z choroba nowotworowa $w$ doświadczeniu pacjentów. Toruń: Wydawnictwo UMK.

Block, B. (2006). Czy można umierać bez lęku? Paedagogia Christiana, 1/17, 47-60.

Bohusz-Dobosz, A. (2004). Choroba terminalna i metody łagodzenia jej skutków. In W. Falkowski, E. Lewandowska-Tarasiuk \& J. W. Sienkiewicz (Eds.), Hospicja nadziei (pp. 145-159). Warszawa: Wydawnictwo Akademii Pedagogiki Specjalnej.

Borneman, T., Ferrell, B. \& Puchalski, C. M. (2010). Evaluation of the FICA Tool for Spiritual Assessment. Journal of Pain and Symptom Management, 40(2), 1, 63-173. http:// 10.1016/j.jpainsymman.2009.12.019

Brady, M. J., Peterman, A. H., Fitchett, G.. Mo, M. \& Cella, D. (1999). A case for including spirituality in quality of life measurement in oncology. Psycho-Oncology 8, 417-428. http://dx.doi.org/10.1002/(SICI)1099-1611(199909/10)8:5< 417::AID-PON398>3.0.CO;2-4

Comte-Sponville, A. (2011). Duchowość ateistyczna. Wprowadzenie do duchowości bez Boga. Warszawa: Czarna Owca.

Fabiś, A. (2015). Rozwój duchowy jako atrybut dojrzałości w starości. Biblioteka Gerontologii Społecznej, 1(9), 11-18.

Fopka-Kowalczyk, M. (2017). Jak rozmawiać z dziećmi o chorobie, cierpieniu i śmierci. Opowiadania i bajki. Warszawa: Difin.

Frankl, V. E. (1985). Man's Search for Meaning. New York-London-Toronto-Sydney: Pocket Book.

Frankl, V. E. (2017). Lekarz i dusza. Wprowadzenie do logoterapii i analizy egzystencjalnej. Warszawa: Czarna Owca.

Grochans, E., Bąk, A., Reczyńska, A., Jurczak, A., Szkup-Jabłońska, M. \& Brzostek, B. (2012). Ocena jakości życia chorych z przewlekłymi chorobami układu oddechowego. Probl Hig Epidemiol, 93(3), 542-545. http://www.phie.pl/pdf/ phe-2012/phe-2012-3-542.pdf

Groves, R. \& Klauser H. A. (2009). The American Book of Living and Dying: Lessons in Healing Spiritual Pain. Berkeley: Celestial Arts.

National Institute for Clinical Excellence (NICE) (2004). Guidance on Cancer Services. Improving supportive and palliative care for adults with cancer. The 
Manual. Retrieved February 25, 2017 form http://www.nice.org.uk/Guidance/ CSGSP/Guidance/pdf/.

Heszen-Niejodek, I. \& Gruszczyńska, E. (2004). Wymiar duchowy człowieka, jego znaczenie w psychologii zdrowia i jego pomiar. Przeglad Psychologiczny, 2, $15-31$.

Jundziłł E. \& Pawłowska, R. (2008). Pedagogika opiekuńcza. Przeszłość - teraźniejszość - przyszłość. Gdańsk: Harmonia.

Kapała, M. (2017). Duchowość jako nieoceniony aspekt psyche. Propozycja nowego ujęcia duchowości w psychologii - kategoria wrażliwości duchowej. Annales Universitatis Maiae Curie-Skłodowska, 1, 7-37. doi: https://10.17951/ j.2016.30.1.7

Karches, K. E., Chung, G. S., Arora, V., Meltzer, D. O. \& Curlin, F.A. (2012). Religiosity, Spirituality, and End-of-Life Planning: A Single-Site Survey of Medical Inpatients. Journal of Pain and Symptom Management, 6, 843-851. https:// 10.1016/j.jpainsymman.2011.12.277

Kolasa, D. (2010). Sytuacje możliwe a sytuacje graniczne w filozofii Jaspersa. Studia z historii filozofii, 1, 135-145.

Klimasiński, M. W., Płocka, M., Neuman-Klimasińska, N. \& Pawlikowski, J. (2017a). Czy lekarze powinni udzielać wsparcia duchowego swoim pacjentom - przegląd badań. Medycyna Praktyczna, 3, 128-133.

Klimasiński, M. W., Ziemkiewicz, M. \& Neumann-Klimasińska, N. (2017b). Potrzeby duchowe pacjentów istotne w codziennej praktyce klinicznej. Medycyna Paliatywna, 9(4), 210-217.

Krakowiak, P. \& Fopka-Kowalczyk, M. (2015). Włączanie wymiaru duchowego w działania pracowników socjalnych przez adaptację narzędzia do badania potrzeb duchowych. In E. Bojanowska \& M. Kawińska (Eds.), Praca socjalna wobec wyzwań współczesności (pp. 55-68). Warszawa: Kontrast.

Krajnik, M. (2017). Dusza pacjenta jest tak samo ważna jak ciało. Retrieved February 18, 2018 from https://pl.aleteia.org/2017/02/11/dusza-pacjenta-jest-taksamo-wazna-jak-cialo-opieka-duchowa-w-medycynie/.

Kübler-Ross, E. (2007). Rozmowy o śmierci i umieraniu. Poznań: Media Rodzina.

Kurpas, D., Kusz, J., Jedynak, T. \& Mroczek, B. (2012). Stopień akceptacji choroby przewlekłej wśród pacjentów. Family Medicine \& Primary Care Review, 3, 396-398.

Laarhoven van, H. W. M., Schilderman, J., Vissers, K. C., Verhagen C. A. H. H. V. M. \& Prins, J. (2010). Images of God in Relation to Coping Strategies of Palliative Cancer Patients. Journal of Pain and Management, 4, 495-501. https://doi. org/10.1016/j.jpainsymman.2010..02.021

Larkin, P. (2018). Compassion as a basic of care for people in difficult situations. 
Lecture opened at the Nicolaus Copernicus University of Poland in Torun on 6.12.2018.

Marek, Z. \& Walulik, A. (2012). Sytuacje graniczne i wychowanie. Paedagogia Christiana, 2/30, 179-191.

Markocka-Mączka, K., Grabowski, K. \& Toboła, R. (2016). Choroby przewlekłe problem XXI wieku. In E. Dybińska \& B. Zboina (Eds.), Dobrostan a edukacja (pp. 177-186). Lublin: NeuroCentrum.

Mausch, K. (2018). Psychologia w obszarze pomagania innym. Gorzów Wielkopolski: Wydawnictwo Naukowe Akademii im. Jakuba z Paradyża.

Mikołajczak, J. (2017). Logoterapia, czyli o psychoterapii stworzonej przez Viktora Frankla. Retrieved January 14, 2020 from http:/opusanima.pl/logoterapia/.

Muszala, A. (2017a). Komentarz. In A. Vandenhoeck, Kapelani jako specjaliści od opieki duchowej nad pacjentami w Europie. Medycyna Praktyczna, 2, 124-125.

Muszala, A. (2017b). Konsultacje duchowe jako praktyczne wsparcie dla lekarzy w podejmowaniu decyzji medycznych. Retrieved February 18, 2019 from https://www.mp.pl/etyka/kres_zycia/171441,konsultacje-duchowe-jako-prakty czne-wsparcie-dla-lekarzy-w-podejmowaniu-decyzji-medycznych.

Nolan, S., Saltmarsh, P. \& Leget, C. (2011), Spiritual care in palliative care: working towards an EAPC Task Force. European Public Low, 18, 86-89.

Pawlak, Z. (2000). Opieka duchowa w terminalnej fazie choroby. Nowa Medycyna, 1. Retrieved February 1, 2018 form http:/www.czytelniamedyczna.pl/1318,opieka-duchowa-w-terminalnej-fazie-choroby.html.

Puchalski, Ch. (2013). Uwzględnianie duchowości w opiece nad chorym - niezbędny element opieki zorientowanej na pacjenta. Polskie Archiwum Medycyny Wewnętrznej, 123, 491-497.

Puchalski, Ch. \& Romer, A. (2000). Taking a spiritual history allows clinicians to understand patients more fully. Journal of Palliative Medicine, 3, 129-137.

Puchalski, Ch., Ferrell, B., Virani, R., Otis-Green, S., Baird, P., Bull, J., Chochinov, H, Handzo, G., Nelson-Becker, H., Prince-Paul, M., Pugliese, K., Sulmasy, D. (2009). Improving the quality of spiritual care as a dimension of palliative care: the report of the consensus conference. Journal of Palliative Medicine, 12(10), 885-904. DOI: 10.1089=jpm.2009.0142

Reynolds, R., Dennis, S., Hasan, I., Slewa, J., Chen, W., Tian, D., Bobba, S. \& Zwar, N. (2018). A systematic review of chronic disease management interventions in primary care. Bio Med Central Family Practice, 19(11), 1-13. doi: 10.1186/ s12875-017-0692-3

Saunders, C. (2004). Trwałe zasady hospicjum. In W. Falkowski, E. Lewandowska-Tarasiuk \& J. W. Sienkiewicz (Eds.), Hospicja nadziei. Warszawa: Wydawnictwo Akademii Pedagogiki Specjalnej. 
Sęk, H. \& Cieślak, R. (2206). Wsparcie społeczne - sposoby definiowania, rodzaje i źródła wsparcia, wybrane koncepcje teoretyczne. In H. Sęk \& R. Cieślak (Eds.), Wsparcie społeczne, stres i zdrowie. Warszawa: PWN.

Swinton, M., Giacomi, M., Toledo, F., Trudy R., Hand-Breckenridge, T., Boyle, A., Woods, A., Clarke, F., Shears, M., Sheppard, R. \& Cook, D. (2017). Experiences and Expressions of Spirituality at the End of Life in the Intensive Care Unit. American Journal of Respiratory and Critical Care Medicine, 2, 198-204. https://doi.org/10.1164/rccm.201606-1102OC

Świętochowski, W. (2010). System rodzinny wobec przewlektej choroby somatycznej. Łódź: Wydawnictwo Uniwersytetu Łódzkiego.

Szparkowska, S. (2013). Opieka duchowa nad pacjentem - zbędny luksus czy niezbędny element leczenia? Retrieved April 5, 2013 from www.mp.pl.

Tatar, M. (2012). Duchowość cierpienia wobec wybranych ujęć psychologii. Warszawskie Studia Pastoralne, 15, 133-160.

Honings, B. (1995). The Charter for Healthcare Workers: A Synthesis of Hippocratic Ethics and Christian Morality. Retrieved February 1, 2018, from http://www. vatican.va/roman_curia/pontifical_councils/hlthwork/documents/rc_pc_hlthwork_doc_30061997_honings_en.html.

Urbański-Korż, R. (Ed.) (2000). Kompetencje społeczne dorostych. Język-dobropiękno - śmierć. Toruń-Poznań: Edytor.

Walden-Gałuszko de, K. (1992). Wybrane zagadnienia psychoonkologii i psychotanatologii. Gdańsk: Wydawnictwo UG.

Winkler, B. (1996). Ból nowotworowy jako zjawisko somatopsychiczne. In B. Siwek (Ed.), Problemy medycyny paliatywnej w onkologii. Lublin: Wojewódzki Zespół Ekonomiki i Polityki Zdrowotnej w Lublinie.

Wojdała, B. (2016). Sytuacja pacjenta jako sytuacja graniczna. Psychoterapia, 1, $77-86$.

Vandenhoeck, A. (2013). Chaplains as specialists in spiritual care for patients in Europe. Polskie Archiwum Medycyny Wewnętrznej, 123(10), 552-557.

Vandenhoeck, A. (2017) Opieka duchowa nad chorymi - rozwiązania w krajach Unii Europejskiej. Retrieved February 27, 2017 from http://www.mp.pl/wideo $01 / ? \mathrm{id}=1264$. 